\title{
Patterns of TPD52 overexpression in multiple human solid tumor types analyzed by quantitative PCR
}

\author{
PIERRE TENNSTEDT $^{1 *}$, CHARLOTTE BÖLCH ${ }^{2 *}$, GUNDULA STROBEL $^{2}$, SARAH MINNER $^{2}$, LIA BURKHARDT $^{2}$, \\ TOBIAS GROB ${ }^{2}$, SAWINEE MASSER ${ }^{2}$, GUIDO SAUTER ${ }^{2}$, THORSTEN SCHLOMM $^{1,3}$ and RONALD SIMON ${ }^{2}$ \\ ${ }^{1}$ Martini-Clinic, ${ }^{2}$ Institute of Pathology, ${ }^{3}$ Department of Urology, Section for Translational Prostate Cancer Research, \\ University Medical Center Hamburg-Eppendorf, Hamburg, Germany
}

Received September 24, 2013; Accepted October 29, 2013

DOI: $10.3892 /$ ijo.2013.2200

\begin{abstract}
Tumor protein D52 (TPD52) is located at chromosome $8 \mathrm{q} 21$, a region that is frequently gained or amplified in multiple human cancer types. TPD52 has been suggested as a potential target for new anticancer therapies. In order to analyze TPD52 expression in the most prevalent human cancer types, we employed quantitative PCR to measure TPD52 mRNA levels in formalin-fixed tissue samples from more than 900 cancer tissues obtained from 29 different human cancer types. TPD52 was expressed at varying levels in all tested normal tissues, including skin, lymph node, lung, oral mucosa, breast, endometrium, ovary, vulva, myometrium, liver, pancreas, stomach, kidney, prostate, testis, urinary bladder, thyroid gland, brain, muscle and fat tissue. TPD52 was upregulated in 18/29 (62\%) tested cancer types. Strongest expression was found in non-seminoma (56-fold overexpression compared to corresponding normal tissue), seminoma (42-fold), ductal (28-fold) and lobular breast cancer (14-fold). In these tumor types, TPD52 upregulation was found in the vast majority ( $>80 \%$ ) of tested samples. Downregulation was found in $11(38 \%)$ tumor types, most strongly in papillary renal cell cancer (-8-fold), leiomyosarcoma (-6-fold), clear cell renal cell cancer (-5-fold), liposarcoma (-5-fold) and lung cancer (-4-fold). These results demonstrate that TPD52 is frequently and strongly upregulated in many human cancer types, which may represent candidate tumor types for potential anti-TPD52 therapies.
\end{abstract}

\section{Introduction}

Copy number increase involving chromosome $8 \mathrm{q}$ belong to the most frequent aberrations in human solid cancers, including

Correspondence to: Dr Ronald Simon, Institute of Pathology, University Medical Center Hamburg-Eppendorf, Martinistrasse 52, D-20246 Hamburg, Germany

E-mail: r.simon@uke.uni-hamburg.de

*Contributed equally

Key words: TPD52, cancer, real-time PCR, mRNA analysis, normal tissue for example tumors of the breast, ovary, endometrium, lung, colon, head and neck, urinary bladder, kidney and prostate $(1,2)$. Whereas gains often affect large portions of $8 \mathrm{q}$ or even the entire q-arm, high-level amplifications are typically focused on the chromosomal bands 8q21 (3-5) and 8q24 (6,7), thus highlighting the loci of putative oncogenes, including MYC at $8 q 24$. Several candidate oncogenes have been suggested to reside inside the $8 \mathrm{q} 21$ region, including tumor protein D52 (TPD52) $(3,8-13)$. TPD52 has been suggested to play a role for vesicle trafficking and $\mathrm{Ca}^{2+}$ dependent exocytotic secretion, and has been shown to facilitate cytokinesis in rapidly proliferating cells $(14,15)$.

In line with an oncogenic role, TPD52 overexpression has been described from a multitude of cancer types, including breast (9), lung prostate (2), ovarian (8), pancreatic cancer (16), multiple myeloma $(17,18)$, Burkitt's lymphoma (19), melanoma (20) and testicular germ cell tumors (21), and has been linked to poor prognosis in breast, medulloblastoma, lung and prostate cancer patients (22). Moreover, cell line experiments and in vivo analysis in mice support the implication of TPD52 in tumorigenesis and progression to metastasis $(23,24)$. Accordingly, TPD52 has been suggested as a promising target for antitumor therapies in breast (25) and prostate cancer (24), and it seems likely that also other tumor types showing TPD52 overexpression could profit from a TPD52 specific therapy.

A systematic analysis of TPD52 expression in human cancers in order to identify tumor types that might benefit from potential anti-TPD52 therapies is lacking. In this study, we have employed quantitative real-time PCR in more than 900 tumor samples to compare the prevalence and expression levels of TPD52 across 29 important human cancer types and corresponding normal tissues.

\section{Materials and methods}

Tissue specimens. Formalin-fixed, paraffin embedded tissues were selected from the archive of the Institute of Pathology, University Medical Center Hamburg-Eppendorf (Hamburg, Germany). A total of 999 cancer samples and 40 normal tissue samples were included into the study. A detailed list of all samples is given in Table I. One pathologist reviewed all hematoxylin and eosin stained sections of all tissues and selected one block per tumor for RNA isolation. For tumor 
Table I. Tissue samples for TPD52 expression analysis.

\begin{tabular}{|c|c|c|c|c|}
\hline Tissue type & Organ & $\mathrm{n}$ & Organ & $\mathrm{n}$ \\
\hline \multirow[t]{10}{*}{ Normal } & Skin & 2 & Pancreas & 1 \\
\hline & Lymph node & 2 & Stomach & 2 \\
\hline & Lung & 2 & Kidney & 2 \\
\hline & Oral cavitiy & 2 & Prostate & 2 \\
\hline & Breast & 1 & Testis & 3 \\
\hline & Endometrium & 2 & Bladder & 2 \\
\hline & Ovar & 2 & Thyroid gland & 2 \\
\hline & Vulva & 2 & Brain & 2 \\
\hline & Myometrium & 2 & Skeletal muscle & 2 \\
\hline & Liver & 3 & Adipose tissue & 2 \\
\hline \multirow[t]{12}{*}{ Cancer } & Malignant melanoma & 11 & Liver cancer & 50 \\
\hline & Larynx carcinoma & 39 & Pancreatic cancer & 38 \\
\hline & $\begin{array}{l}\text { Lung cancer, large cell (24), } \\
\text { adeno }(68), \text { small cell }(17)\end{array}$ & & & \\
\hline & and squamous cell (25) & 134 & Stomach cancer & 50 \\
\hline & Oral cavity cancer & 56 & Renal cell cancer & 59 \\
\hline & $\begin{array}{l}\text { Breast cancer, ductal (26) } \\
\text { and lobular (27) }\end{array}$ & 53 & Prostate cancer & 48 \\
\hline & Endometrium carcinoma & 31 & $\begin{array}{l}\text { Testis cancer, seminoma (30) } \\
\text { and non-seminoma (29) }\end{array}$ & 59 \\
\hline & Ovarian cancer & 33 & $\begin{array}{l}\text { Urinary bladder cancer, } \\
\text { non-invasive (pTa 27) } \\
\text { and invasive ( } \geq \text { pT2 28) }\end{array}$ & 55 \\
\hline & Uterus cervix carcinoma & 28 & Thyroid gland cancer & 40 \\
\hline & Vulva cancer & 39 & Leiomyosarcoma & 42 \\
\hline & Colon cancer & 50 & Liposarcoma & 36 \\
\hline & $\begin{array}{l}\text { Esophageal cancer, } \\
\text { squamous cell }(23) \\
\text { and adenocarcinoma ( } 25)\end{array}$ & 48 & & \\
\hline
\end{tabular}

samples areas with high tumor cell content ( $\geq 60 \%$ tumor cells) were marked on the slide. A hollow needle was used to take two tissue cylinders (diameter from $0.5 \mathrm{~mm}$ ) from each tissue block for nucleic acid isolation. The local ethics committee approved usage of the human tissue samples for research purposes.

RNA extraction and cDNA synthesis. Punched tissue material was deparaffinized with xylene and $80 \%$ ethanol. After digestion with proteinases $\mathrm{K}$ at $56^{\circ} \mathrm{C}$ overnight, total RNA was isolated using the RNeasy FFPE kit (Qiagen) in a fullautomated nucleic acid isolation device (QIAcube, Qiagen). cDNA was synthesized in a 96-well plate format using the high-capacity cDNA reverse transcription kit (Applied Biosystems) following the manufacturer's instructions. Total RNA $(1 \mu \mathrm{g})$ was used for reverse transcription of all samples.

Quantitative PCR analysis. Real-time PCR was performed using the LightCycler LC480 (Roche) detection system, and the QuantiTect SYBR-Green PCR Kit (Qiagen). For specific amplification of TPD52 and the housekeeping gene TBP the QuantiTect Primer Assay (Qiagen) was used. The following conditions were used for PCR: i) initial denaturation step at $95^{\circ} \mathrm{C}$ for $10 \mathrm{~min}$; and ii) 40 cycles at $95^{\circ} \mathrm{C}$ for $20 \mathrm{sec}$ and $55^{\circ} \mathrm{C}$ for $40 \mathrm{sec}$. Relative quantity of TPD52 expression in tumor samples was calculated by the $2^{-\Delta \Delta \mathrm{Ct}}$ method standardized to TPD52 expression in corresponding normal tissue. A fold change of 2 was used to determine the frequency of significant TPD52 regulated cancers.

\section{Results}

Technical issue. A total of 894 cancer samples from 29 different tumor types and 40 normal tissue samples from 20 different normal tissue types were included in the analysis (Table I). A total of $105(10.5 \%)$ tumor samples and $3(7.5 \%)$ normal tissue samples were excluded from analysis because either the reference gene $T B P$ or the target gene TPD52 showed a $\mathrm{Ct}$ value exceeding 35 , indicating that too little cDNA was generated for reliable TPD52 expression analysis. 


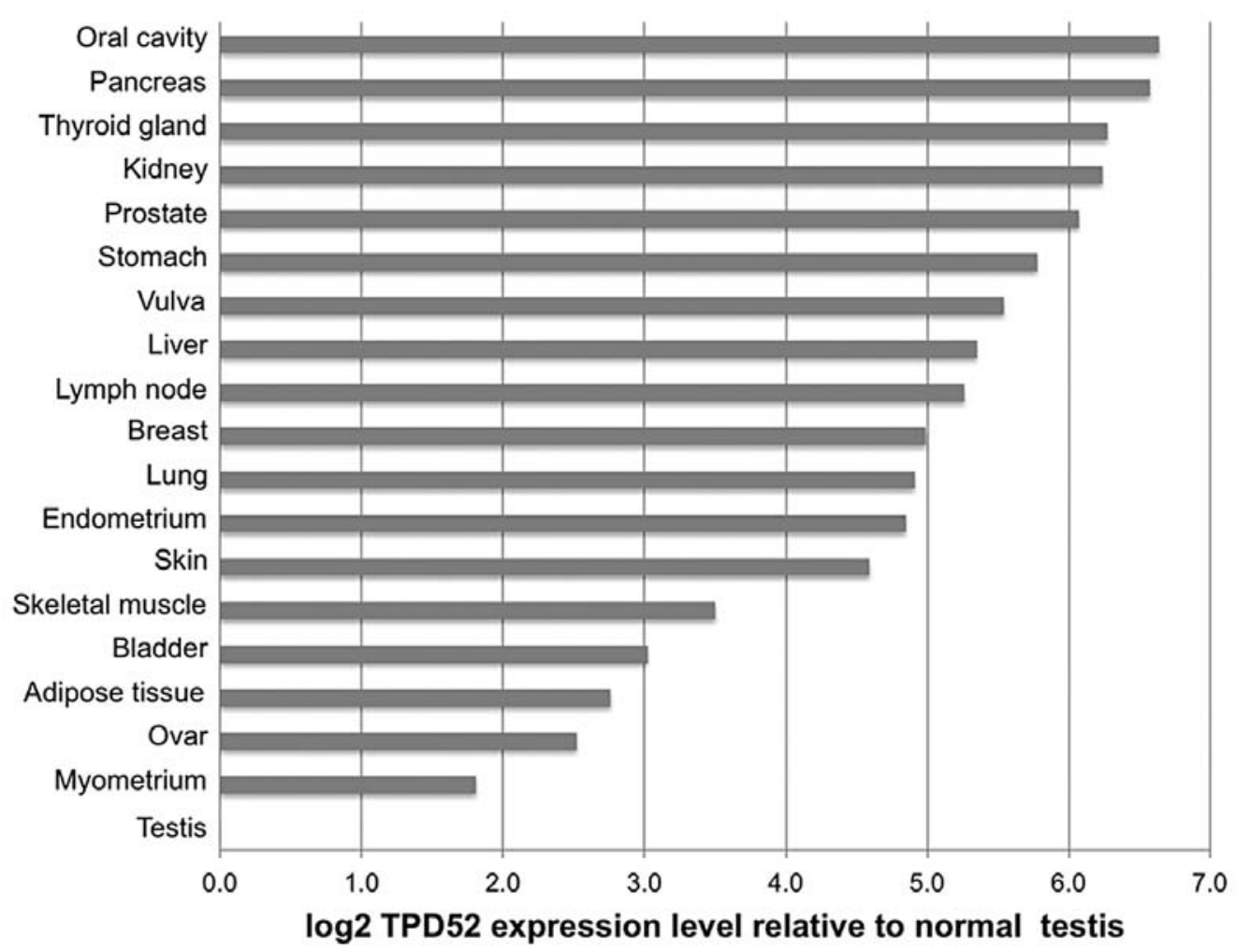

Figure 1. TPD52 expression levels in different normal tissue. Relative TPD52 expression level (log2) was standardized to TPD52 expression in testis.

TPD52 expression in normal tissues. TPD52 transcript was found in all analyzed normal tissues. Average $\Delta \mathrm{Ct}$ was $2.4 \pm 0.4$. For a direct comparison of the TPD52 expression levels of the different normal tissues, the expression levels were normalized to the TPD52 expression level in testis, which had the lowest expression level of all analyzed normal tissues. Accordingly, highest TPD52 expression levels [ $\geq 32\left(2^{5}\right)$-fold overexpression as compared to normal testis] were found in normal oral cavity mucosa (104-fold overexpression), pancreas (91-fold), thyroid gland (79-fold), kidney (76-fold), prostate (69-fold), stomach (56-fold), vulva (45-fold), liver (39-fold), lymph node (38-fold), and breast (32-fold). All data are summarized in Fig. 1.

TPD52 expression in cancer. To compare TPD52 expression across the different tumor types, average expression levels in the cancer samples were normalized to the corresponding normal tissue. For cancer types without available corresponding normal tissues, the average expression level of all normal tissues $(\Delta \mathrm{Ct}=2.4 \pm 0.4)$ was used for normalization. These cancer types included tumors of the larynx, cervix, esophagus and colon. This analysis revealed $\geq 1.5$-fold TPD52 overexpression in 18/29 $(62 \%)$ analyzed tumor types, with highest levels in non-seminoma (56-fold overexpression compared to corresponding normal tissue), seminoma (42-fold), ductal breast cancer (28-fold) and lobular breast cancer (14-fold). Downregulation as compared to the corresponding normal tissues was found in $11(38 \%)$ of the analyzed tumor types, including papillary renal cell cancer (-8-fold), leiomyosarcoma (-6-fold), clear cell renal cell cancer (-5-fold), liposarcoma (-5-fold) and lung cancer (-4-fold) as the tumor types with the strongest downregulation. All data are summarized in Fig. 2.
Prevalence of TPD52 expression in cancer. In order to estimate the variability of TPD52 expression in the analyzed tumor types, we determined the fraction of samples showing at least 2-fold up- or downregulation. This analysis revealed that TPD52 overexpression was particular frequent $(80 \%$ of samples showing $\geq 2$-fold overexpression) in germ cell tumors (non-seminoma and seminoma), bladder cancer, esophageal carcinoma and mamma carcinoma, whereas cancer types typically showing TPD52 downregulation included renal cell carcinoma $(90 \%$ papillary and $68 \%$ clear cell), leiomyosarcoma (69\%) and liposarcoma (52\%). All data are shown in Fig. 3.

\section{Discussion}

The results of our study show that TPD52 is overexpressed in a multitude of human solid cancer types. Lower TPD52 levels were also found in the corresponding normal tissues, which is in concordance with previous studies reporting TPD52 expression in normal tissues derived from breast (25-28), prostate (29-31), ovarian (8), lung (32-34), bladder (35), brain (36), thyroid (37), endometrium $(38,39)$, adrenal gland (40) and liver (41). Such low-level expression was expected given the essential role of TPD52 for vesicle trafficking and exocytotic secretion (14).

Many cancer types analyzed in our study were characterized by massive TPD52 overexpression. Overexpression was strongest and also most prevalent in breast cancers, urinary bladder cancers and in testicular cancers. Our data are in agreement with previous studies reporting TPD52 overexpression in breast cancer [7-47\%, (3,42-50)]; bladder cancer $[21 \%,(4)]$, prostate cancer $[44-68 \%,(2,13,29)]$ and 


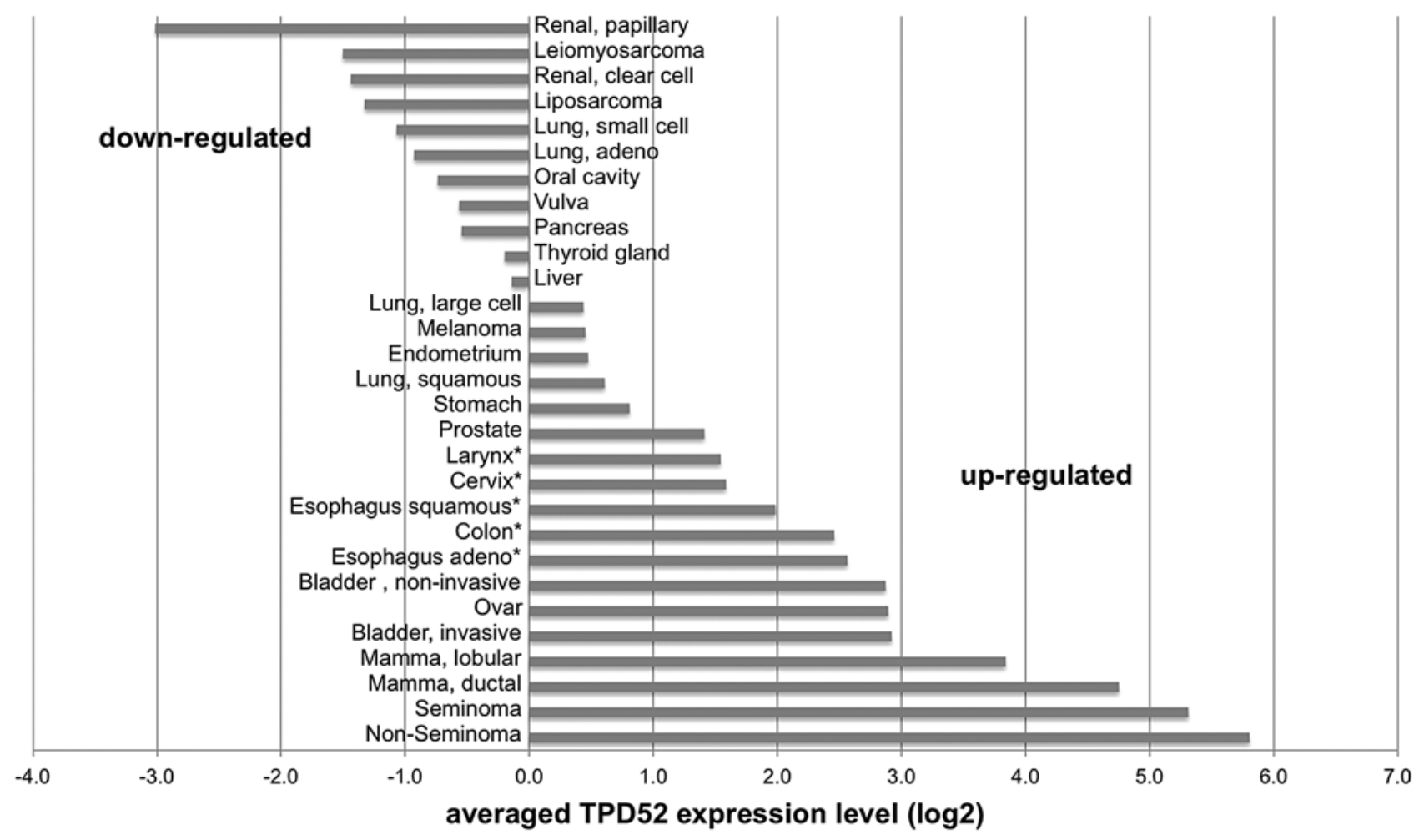

Figure 2. TPD52 averaged expression levels in different cancer types. TPD52 expression was normalized to corresponding normal tissue or mean TPD52 expression in all analyzed normal tissue (*).

\section{$\geq 2$ fold down-regulated}

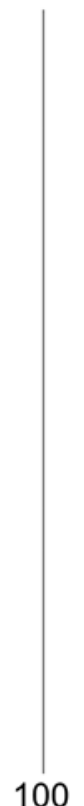

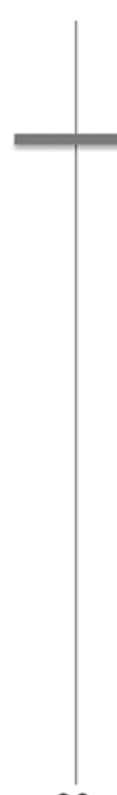

80

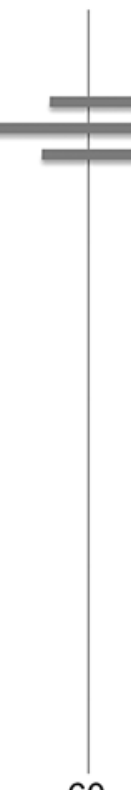

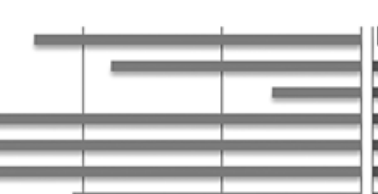
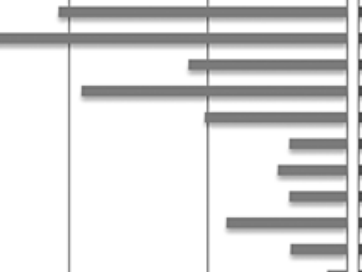

5
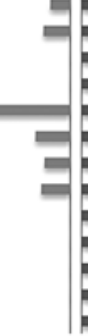

40

泟

0

20
Lung, small cell Oral cavity -Thyroid gland Renal, clear cell Renal, papillary Leiomyosarcoma Lung, adeno Liposarcoma Pancreas Vulva

Liver Lung, large cell Lung, squamous Endometrium Stomach Prostate Prostate

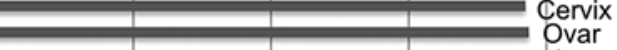

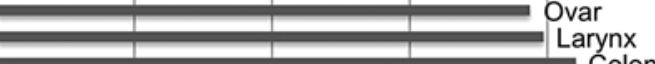
\begin{tabular}{|l|l|l|l}
\hline & Esophagus squamous \\
\hline
\end{tabular} Mamma, lobular

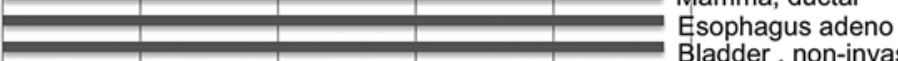
Bladder, non-invasive Seminoma

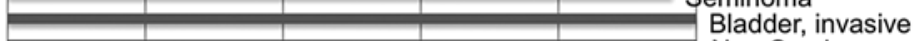

40

60

80100

Frequency in \% of cancer samples showing TPD52 over- or under-expression

Figure 3. Frequency of TPD52 up- and downregulation in different tumor types. A fold change of 2 was determined to find significant TPD52 regulated tumors.

ovarian cancer $[61 \%,(8)]$ (Table II). Of note, these tumor types are frequently affected by gains of $8 \mathrm{q}$ or even high-level amplification of the TPD52 locus at chromosome 8q21 (3,29), suggesting that at least part of the observed overexpression in these cancers may be driven by genomic copy number gains of TPD52. In line with this assumption, numerous previous 
Table II. Overview of cancer types with differential TPD52 expression from the literature.

\begin{tabular}{|c|c|c|}
\hline Tumor type & $\begin{array}{c}\text { TPD52 } \\
\text { downregulation } \\
\text { (Refs.) }\end{array}$ & $\begin{array}{c}\text { TPD52 } \\
\text { overexpression } \\
\text { (Refs.) }\end{array}$ \\
\hline Malignant melanoma & & $\left(20,67^{\mathrm{a}}\right)$ \\
\hline \multicolumn{3}{|l|}{ Larynx carcinoma } \\
\hline Lung cancer & & $\left(32^{\mathrm{a}}, 33^{\mathrm{a}}, 68^{\mathrm{a}}-72^{\mathrm{a}}\right)$ \\
\hline \multicolumn{3}{|l|}{ Oral cavity cancer } \\
\hline Breast cancer & & $\begin{array}{c}(9,11,12,22,25, \\
26,42,43,73-75)\end{array}$ \\
\hline \multicolumn{3}{|l|}{ Endometrium carcinoma } \\
\hline Ovarian cancer & & $\left(8,76-78^{a}\right)$ \\
\hline \multicolumn{3}{|l|}{ Uterus cervix carcinoma } \\
\hline \multicolumn{3}{|l|}{ Vulvar cancer } \\
\hline Colon cancer & $\left(61^{\mathrm{a}}, 62\right)$ & $\left(77-81^{a}\right)$ \\
\hline \multicolumn{3}{|l|}{ Esophageal cancer } \\
\hline Liver cancer & & $\left(82^{a}\right)$ \\
\hline Pancreatic cancer & & (16) \\
\hline \multicolumn{3}{|l|}{ Stomach cancer } \\
\hline \multicolumn{3}{|l|}{ Renal cell cancer } \\
\hline Prostate cancer & & $(2,10,13,24,83-88)$ \\
\hline Testis cancer & & $\left(21^{\mathrm{a}}, 63^{\mathrm{a}}, 64^{\mathrm{a}}\right)$ \\
\hline Urinary bladder cancer & & $\left(89^{\mathrm{a}}, 90^{\mathrm{a}}\right)$ \\
\hline \multicolumn{3}{|l|}{ Thyroid gland cancer } \\
\hline \multicolumn{3}{|l|}{ Leiomyosarcoma } \\
\hline Liposarcoma & & \\
\hline
\end{tabular}

${ }^{\mathrm{a}}$ References are Oncomine ${ }^{\mathrm{TM}}$ analysis for TPD52 using the following criteria: $\mathrm{p}<0.01$, at least 2 -fold differential expression.

studies reported associations between TPD52 overexpression and gene copy number increase in breast $(9,12,42,43,45)$, prostate (2) and ovarian cancers (8).

We found substantial TPD52 downregulation in papillary and clear cell kidney cancers, leio- and liposarcomas. Since these cancers do not typically show genomic loss of $8 \mathrm{q}$, it seems obvious that downregulation is not primarily due to TPD52 deletions but may be a result of modified transcription due to genetic or epigenetic regulation. TPD52 downregulation was also reported from leukemia (51-53), lymphoma $(54,55)$, brain cancer $(36,56-58)$ and sarcoma (59).

The good concordance of our results as compared to published studies underlines the validity of our analysis. Only few tumor types analyzed in our study showed discrepant results as compared to the literature, including pancreatic cancer, melanoma and colon cancer. It is possible, that these discrepancies are due to technical differences in the first place. For example, Loukopoulos et al (16) demonstrated upregulation of TPD52 in all 42 analyzed tumors, but analyzed xenografts instead of primary tumors in order to artificially maximize the fraction of tumor cells in the sample. Riker et al (60), Skrzypczak et al (61) and Hong et al (62) reported downregulation of TPD52 expression in colon cancer, whereas upregulation was found in our analysis. We did not include normal colon as a reference in our study but used an average expression value across all analyzed normal tissues as a surrogate. It is possible, that this strategy resulted in bias. The same may also apply for our results obtained from larynx, cervix and esophageal carcinomas, where we used the same 'average' reference.

The usage of matched normal tissues for reference in the vast majority of our samples enabled us to estimate the relative impact of TPD52 in the individual tumor types. Testicular germ cell cancers showed the highest levels and frequency of TPD52 expression, suggesting that TPD52 upregulation might play a particularly important role in this tumor type. Comparative genomic hybridization data suggest that large fractions of chromosome 8q, including the TPD52 locus, can be frequently $[42-70 \%,(21,63,64)]$ gained or amplified $(21)$ in testicular germ cell cancers, supporting a role of genomic gains for the overexpression also in this cancer type. This is consistent with overexpression of TPD52 in testicular germ cell tumors with CGH-confirmed $8 \mathrm{q}$ copy number gains reported by Scotheim et al (21).

We identified several additional tumor types with frequent ( $\geq 50 \%$ of samples) TPD52 overexpression that had not been reported before, including endometrial carcinomas, cervix cancer, and stomach cancers. Also these cancers are frequently affected by $8 \mathrm{q}$ gains or even amplifications (5), further supporting the concept of TPD52 copy number alterations represent an important mechanism of TPD52 overexpression (Fig. 3).

The large number of tumor types showing TPD52 overexpression in a significant fraction of samples encourages clinical testing of anti-TPD52 therapies. Payton et al have shown that TPD52 protein-based vaccination in mice induced an adaptive immune response capable of rejecting TPD52-overexpression induced tumorigenesis (65). Lewis et al have shown that TRAMP (transgenic adenocarcinoma of the mouse prostate) mice immunized with cDNA for mD52 as a DNA-based vaccine survived tumor cell challenge through a specific $\mathrm{T}_{\mathrm{H}} 1$-type $\mathrm{T}$ cell response (66). Our data suggest that such a therapy, if effective, could be applied also to a broad range of other tumor types. This is particularly true for cancers with strong overexpression in the tumor cells as compared to the corresponding normal tissue, including for example testicular germ cell cancers. Our finding, that breast cancer ranks second as a tumor type with strong cancer-related TPD52 expression level changes emphasized the potential of anti-TPD52 therapy in this tumor type.

In summary, our data demonstrate that TPD52 overexpression is common in many tumor types. Particularly strong TPD52 upregulation was found in cancers of the breast, urinary bladder cancer and testicular germ cell cancers, which frequently harbor $8 \mathrm{q}$ gains. These tumor types may be particularly promising candidates for potential anti-TPD52 therapies.

\section{Acknowledgements}

We thank Christina Koop, Inge Brandt, Jannette Lütgens and Bianca Kelp for excellent technical assistance. 


\section{References}

1. Schraml P, Kononen J, Bubendorf L, et al: Tissue microarrays for gene amplification surveys in many different tumor types. Clin Cancer Res 5: 1966-1975, 1999.

2. Rubin MA, Varambally S, Beroukhim R, et al: Overexpression, amplification, and androgen regulation of TPD52 in prostate cancer. Cancer Res 64: 3814-3822, 2004.

3. Choschzick M, Lassen P, Lebeau A, et al: Amplification of 8q21 in breast cancer is independent of MYC and associated with poor patient outcome. Mod Pathol 23: 603-610, 2010.

4. Richter J, Jiang F, Gorog JP, et al: Marked genetic differences between stage pTa and stage pT1 papillary bladder cancer detected by comparative genomic hybridization. Cancer Res 57: 2860-2864, 1997.

5. Sauter GH, Munzing W, von Ritter C and Paumgartner G: Bile acid malabsorption as a cause of chronic diarrhea: diagnostic value of 7alpha-hydroxy-4-cholesten-3-one in serum. Dig Dis Sci 44: 14-19, 1999.

6. El Gedaily A, Bubendorf L, Willi N, et al: Discovery of new DNA amplification loci in prostate cancer by comparative genomic hybridization. Prostate 46: 184-190, 2001.

7. Al-Kuraya K, Schraml P, Torhorst J, et al: Prognostic relevance of gene amplifications and coamplifications in breast cancer. Cancer Res 64: 8534-8540, 2004.

8. Byrne JA, Balleine RL, Schoenberg Fejzo M, et al: Tumor protein D52 (TPD52) is overexpressed and a gene amplification target in ovarian cancer. Int J Cancer 117: 1049-1054, 2005.

9. Balleine RL, Fejzo MS, Sathasivam P, Basset P, Clarke CL and Byrne JA: The hD52 (TPD52) gene is a candidate target gene for events resulting in increased 8q21 copy number in human breast carcinoma. Genes Chromosomes Cancer 29: 48-57, 2000.

10. Van Duin M, van Marion R, Vissers K, et al: High-resolution array comparative genomic hybridization of chromosome arm 8q: evaluation of genetic progression markers for prostate cancer. Genes Chromosomes Cancer 44: 438-449, 2005.

11. Hicks J, Krasnitz A, Lakshmi B, et al: Novel patterns of genome rearrangement and their association with survival in breast cancer. Genome Res 16: 1465-1479, 2006.

12. Rodriguez V, Chen Y, Elkahloun A, Dutra A, Pak E and Chandrasekharappa S: Chromosome 8 BAC array comparative genomic hybridization and expression analysis identify amplification and overexpression of TRMT12 in breast cancer. Genes Chromosomes Cancer 46: 694-707, 2007.

13. Kim JH, Dhanasekaran SM, Mehra R, et al: Integrative analysis of genomic aberrations associated with prostate cancer progression. Cancer Res 67: 8229-8239, 2007.

14. Boutros R, Fanayan S, Shehata M and Byrne JA: The tumor protein D52 family: many pieces, many puzzles. Biochem Biophys Res Commun 325: 1115-1121, 2004.

15. Thomas DD, Frey CL, Messenger SW, August BK and Groblewski GE: A role for tumor protein TPD52 phosphorylation in endo-membrane trafficking during cytokinesis. Biochem Biophys Res Commun 402: 583-587, 2010.

16. Loukopoulos P, Shibata $\mathrm{T}$, Katoh H, et al: Genome-wide array-based comparative genomic hybridization analysis of pancreatic adenocarcinoma: identification of genetic indicators that predict patient outcome. Cancer Sci 98: 392-400, 2007.

17. Largo C, Alvarez S, Saez B, et al: Identification of overexpressed genes in frequently gained/amplified chromosome regions in multiple myeloma. Haematologica 91: 184-191, 2006

18. Tiacci E, Orvietani PL, Bigerna B, et al: Tumor protein D52 (TPD52): a novel B-cell/plasma-cell molecule with unique expression pattern and $\mathrm{Ca}(2+)$-dependent association with annexin VI. Blood 105: 2812-2820, 2005.

19. Dave SS, Fu K, Wright GW, et al: Molecular diagnosis of Burkitt's lymphoma. N Engl J Med 354: 2431-2442, 2006.

20. Roesch A, Becker B, Bentink S, et al: Ataxia telangiectasiamutated gene is a possible biomarker for discrimination of infiltrative deep penetrating nevi and metastatic vertical growth phase melanoma. Cancer Epidemiol Biomarkers Prey 16: 2486-2490, 2007

21. Skotheim RI, Autio R, Lind GE, et al: Novel genomic aberrations in testicular germ cell tumors by array-CGH, and associated gene expression changes. Cell Oncol 28: 315-326, 2006.

22. Liu R, Wang X, Chen GY, et al: The prognostic role of a gene signature from tumorigenic breast-cancer cells. N Engl J Med 356: 217-226, 2007.
23. Lewis JD, Payton LA, Whitford JG, et al: Induction of tumorigenesis and metastasis by the murine orthologue of tumor protein D52. Mol Cancer Res 5: 133-144, 2007.

24. Ummanni R, Teller S, Junker H, et al: Altered expression of tumor protein D52 regulates apoptosis and migration of prostate cancer cells. FEBS J 275: 5703-5713, 2008

25. Shehata M, Bieche I, Boutros R, et al: Nonredundant functions for tumor protein D52-like proteins support specific targeting of TPD52. Clin Cancer Res 14: 5050-5060, 2008.

26. Porter D, Lahti-Domenici J, Keshaviah A, et al: Molecular markers in ductal carcinoma in situ of the breast. Mol Cancer Res 1: 362-375, 2003.

27. Sorlie T, Perou CM, Tibshirani R, et al: Gene expression patterns of breast carcinomas distinguish tumor subclasses with clinical implications. Proc Natl Acad Sci USA 98: 10869-10874, 2001.

28. Gruvberger S, Ringner M, Chen Y, et al: Estrogen receptor status in breast cancer is associated with remarkably distinct gene expression patterns. Cancer Res 61: 5979-5984, 2001.

29. Wang R, Xu J, Saramaki O, et al: PrLZ, a novel prostate-specific and androgen-responsive gene of the TPD52 family, amplified in chromosome 8q21.1 and overexpressed in human prostate cancer. Cancer Res 64: 1589-1594, 2004.

30. Dhanasekaran SM, Barrette TR, Ghosh D, et al: Delineation of prognostic biomarkers in prostate cancer. Nature 412: 822-826, 2001.

31. Welsh JB, Sapinoso LM, Su AI, et al: Analysis of gene expression identifies candidate markers and pharmacological targets in prostate cancer. Cancer Res 61: 5974-5978, 2001.

32. Bhattacharjee A, Richards WG, Staunton J, et al: Classification of human lung carcinomas by mRNA expression profiling reveals distinct adenocarcinoma subclasses. Proc Natl Acad Sci USA 98: 13790-13795, 2001.

33. Garber ME, Troyanskaya OG, Schluens K, et al: Diversity of gene expression in adenocarcinoma of the lung. Proc Natl Acad Sci USA 98: 13784-13789, 2001.

34. Beer DG, Kardia SL, Huang CC, et al: Gene-expression profiles predict survival of patients with lung adenocarcinoma. Nat Med 8: 816-824, 2002

35. Dyrskjot L, Thykjaer T, Kruhoffer M, et al: Identifying distinct classes of bladder carcinoma using microarrays. Nat Genet 33: 90-96, 2003.

36. Pomeroy SL, Tamayo P, Gaasenbeek M, et al: Prediction of central nervous system embryonal tumour outcome based on gene expression. Nature 415: 436-442, 2002.

37. Huang Y, Prasad M, Lemon WJ, et al: Gene expression in papillary thyroid carcinoma reveals highly consistent profiles. Proc Natl Acad Sci USA 98: 15044-15049, 2001.

38. Risinger JI, Maxwell GL, Chandramouli GV, et al: Microarray analysis reveals distinct gene expression profiles among different histologic types of endometrial cancer. Cancer Res 63: 6-11, 2003.

39. Mutter GL, Baak JP, Fitzgerald JT, et al: Global expression changes of constitutive and hormonally regulated genes during endometrial neoplastic transformation. Gynecol Oncol 83: 177-185, 2001.

40. Giordano TJ, Thomas DG, Kuick R, et al: Distinct transcriptional profiles of adrenocortical tumors uncovered by DNA microarray analysis. Am J Pathol 162: 521-531, 2003.

41. Chen X, Cheung ST, So S, et al: Gene expression patterns in human liver cancers. Mol Biol Cell 13: 1929-1939, 2002.

42. Pollack JR, Sorlie T, Perou CM, et al: Microarray analysis reveals a major direct role of DNA copy number alteration in the transcriptional program of human breast tumors. Proc Natl Acad Sci USA 99: 12963-12968, 2002.

43. Adelaide J, Finetti P, Bekhouche I, et al: Integrated profiling of basal and luminal breast cancers. Cancer Res 67: 11565-11575, 2007.

44. Pache M, Glatz-Krieger K, Sauter G and Meyer P: Expression of sex hormone receptors and cell cycle proteins in melanocytic lesions of the ocular conjunctiva. Graefes Archive Clin Exp Ophthalmol 244: 113-117, 2006.

45. Jonsson G, Staaf J, Olsson E, et al: High-resolution genomic profiles of breast cancer cell lines assessed by tiling BAC array comparative genomic hybridization. Genes Chromosomes Cancer 46: 543-558, 2007.

46. Bulavin DV, Demidov ON, Saito S, et al: Amplification of PPM1D in human tumors abrogates p53 tumor-suppressor activity. Nat Genet 31: 210-215, 2002. 
47. Parris TZ, Danielsson A, Nemes S, et al: Clinical implications of gene dosage and gene expression patterns in diploid breast carcinoma. Clin Cancer Res 16: 3860-3874, 2010.

48. Hawthorn L, Luce J, Stein L and Rothschild J: Integration of transcript expression, copy number and LOH analysis of infiltrating ductal carcinoma of the breast. BMC Cancer 10: 460, 2010.

49. Melchor L, Alvarez S, Honrado E, et al: The accumulation of specific amplifications characterizes two different genomic pathways of evolution of familial breast tumors. Clin Cancer Res 11: 8577-8584, 2005.

50. Hernandez L, Wilkerson PM, Lambros MB, et al: Genomic and mutational profiling of ductal carcinomas in situ and matched adjacent invasive breast cancers reveals intra-tumour genetic heterogeneity and clonal selection. J Pathol 227: 42-52, 2012.

51. Valk PJ, Verhaak RG, Beijen MA, et al: Prognostically useful gene-expression profiles in acute myeloid leukemia. N Engl J Med 350: 1617-1628, 2004.

52. Maia S, Haining WN, Ansen S, et al: Gene expression profiling identifies BAX-delta as a novel tumor antigen in acute lymphoblastic leukemia. Cancer Res 65: 10050-10058, 2005.

53. Andersson A, Ritz C, Lindgren D, et al: Microarray-based classification of a consecutive series of 121 childhood acute leukemias: prediction of leukemic and genetic subtype as well as of minimal residual disease status. Leukemia 21: 1198-1203, 2007.

54. Basso K, Margolin AA, Stolovitzky G, Klein U, Dalla-Favera R and Califano A: Reverse engineering of regulatory networks in human B cells. Nat Genet 37: 382-390, 2005.

55. Storz MN, van de Rijn M, Kim YH, Mraz-Gernhard S, Hoppe RT and Kohler S: Gene expression profiles of cutaneous B cell lymphoma. J Invest Dermatol 120: 865-870, 2003.

56. Bredel M, Bredel C, Juric D, et al: High-resolution genomewide mapping of genetic alterations in human glial brain tumors. Cancer Res 65: 4088-4096, 2005.

57. Sun L, Hui AM, Su Q, et al: Neuronal and glioma-derived stem cell factor induces angiogenesis within the brain. Cancer Cell 9: 287-300, 2006.

58. Murat A, Migliavacca E, Gorlia T, et al: Stem cell-related 'self-renewal' signature and high epidermal growth factor receptor expression associated with resistance to concomitant chemoradiotherapy in glioblastoma. J Clin Oncol 26: 3015-3024, 2008.

59. Detwiller KY, Fernando NT, Segal NH, Ryeom SW D'Amore PA and Yoon SS: Analysis of hypoxia-related gene expression in sarcomas and effect of hypoxia on RNA interference of vascular endothelial cell growth factor A. Cancer Res 65: 5881-5889, 2005.

60. Riker AI, Enkemann SA, Fodstad O, et al: The gene expression profiles of primary and metastatic melanoma yields a transition point of tumor progression and metastasis. BMC Med Genomics 1: 13, 2008.

61. Skrzypczak M, Goryca K, Rubel T, et al: Modeling oncogenic signaling in colon tumors by multidirectional analyses of microarray data directed for maximization of analytical reliability. PLoS One 5: e13091, 2010.

62. Hong Y, Downey T, Eu KW, Koh PK and Cheah PY: A 'metastasis-prone' signature for early-stage mismatch-repair proficient sporadic colorectal cancer patients and its implications for possible therapeutics. Clin Exp Metastasis 27: 83-90, 2010.

63. Korkola JE, Heck S, Olshen AB, et al: In vivo differentiation and genomic evolution in adult male germ cell tumors. Genes Chromosomes Cancer 47: 43-55, 2008.

64. McIntyre A, Summersgill B, Lu YJ, et al: Genomic copy number and expression patterns in testicular germ cell tumours. Br J Cancer 97: 1707-1712, 2007.

65. Payton LA, Lewis JD, Byrne JA and Bright RK: Vaccination with metastasis-related tumor associated antigen TPD52 and $\mathrm{CpG} / \mathrm{ODN}$ induces protective tumor immunity. Cancer Immunol Immunother 57: 799-811, 2008.

66. Lewis J, Sullivan L, Byrne J, de Riese W and Bright R: Memory and cellular immunity induced by a DNA vaccine encoding self antigen TPD52 administered with soluble GM-CSF. Cancer Immunol Immunother 58: 1337-1349, 2009.

67. Talantov D, Mazumder A, Yu JX, et al: Novel genes associated with malignant melanoma but not benign melanocytic lesions. Clin Cancer Res 11: 7234-7242, 2005.

68. Zhu H, Lam DC, Han KC, et al: High resolution analysis of genomic aberrations by metaphase and array comparative genomic hybridization identifies candidate tumour genes in lung cancer cell lines. Cancer Lett 245: 303-314, 2007.
69. Yamagata N, Shyr Y, Yanagisawa K, et al: A training-testing approach to the molecular classification of resected non-small cell lung cancer. Clin Cancer Res 9: 4695-4704, 2003.

70. Wachi S, Yoneda $\mathrm{K}$ and $\mathrm{Wu} \mathrm{R}$ : Interactome-transcriptome analysis reveals the high centrality of genes differentially expressed in lung cancer tissues. Bioinformatics 21: 4205-4208, 2005.

71. Su LJ, Chang CW, Wu YC, et al: Selection of DDX5 as a novel internal control for Q-RT-PCR from microarray data using a block bootstrap re-sampling scheme. BMC Genomics 8: 140, 2007.

72. Hou J, Aerts J, den Hamer B, et al: Gene expression-based classification of non-small cell lung carcinomas and survival prediction. PLoS One 5: e10312, 2010

73. Yu K, Lee CH, Tan PH and Tan P: Conservation of breast cancer molecular subtypes and transcriptional patterns of tumor progression across distinct ethnic populations. Clin Cancer Res 10: 5508-5517, 2004

74. Scanlan MJ, Gout I, Gordon CM, et al: Humoral immunity to human breast cancer: antigen definition and quantitative analysis of mRNA expression. Cancer Immun 1: 4, 2001.

75. Byrne JA, Tomasetto C, Garnier JM, et al: A screening method to identify genes commonly overexpressed in carcinomas and the identification of a novel complementary DNA sequence. Cancer Res 55: 2896-2903, 1995.

76. Byrne JA, Maleki S, Hardy JR, et al: MAL2 and tumor protein D52 (TPD52) are frequently overexpressed in ovarian carcinoma, but differentially associated with histological subtype and patient outcome. BMC Cancer 10: 497, 2010.

77. Tothill RW, Tinker AV, George J, et al: Novel molecular subtypes of serous and endometrioid ovarian cancer linked to clinical outcome. Clin Cancer Res 14: 5198-5208, 2008.

78. Hendrix ND, Wu R, Kuick R, Schwartz DR, Fearon ER and Cho KR: Fibroblast growth factor 9 has oncogenic activity and is a downstream target of Wnt signaling in ovarian endometrioid adenocarcinomas. Cancer Res 66: 1354-1362, 2006.

79. Petrova DT, Asif AR, Armstrong VW, et al: Expression of chloride intracellular channel protein 1 (CLIC1) and tumor protein D52 (TPD52) as potential biomarkers for colorectal cancer. Clin Biochem 41: 1224-1236, 2008.

80. Buffart TE, Coffa J, Hermsen MA, et al: DNA copy number changes at 8q11-24 in metastasized colorectal cancer. Cell Oncol 27: 57-65, 2005.

81. Kaiser S, Park YK, Franklin JL, et al: Transcriptional recapitulation and subversion of embryonic colon development by mouse colon tumor models and human colon cancer. Genome Biol 8: R131, 2007.

82. Roessler S, Jia HL, Budhu A, et al: A unique metastasis gene signature enables prediction of tumor relapse in early-stage hepatocellular carcinoma patients. Cancer Res 70: 10202-10212, 2010.

83. Wang R, Xu J, Mabjeesh N, et al: PrLZ is expressed in normal prostate development and in human prostate cancer progression. Clin Cancer Res 13: 6040-6048, 2007.

84. Cho-Vega JH, Tsavachidis S, Do KA, Nakagawa J, Medeiros LJ and McDonnell TJ: Dicarbonyl/L-xylulose reductase: a potential biomarker identified by laser-capture microdissection-micro serial analysis of gene expression of human prostate adenocarcinoma. Cancer Epidemiol Biomarkers Prev 16: 2615-2622, 2007.

85. Hendriksen PJ, Dits NF, Kokame K, et al: Evolution of the androgen receptor pathway during progression of prostate cancer. Cancer Res 66: 5012-5020, 2006.

86. Bismar TA, Demichelis F, Riva A, et al: Defining aggressive prostate cancer using a 12-gene model. Neoplasia 8: 59-68, 2006.

87. Rhodes DR, Barrette TR, Rubin MA, Ghosh D and Chinnaiyan AM: Meta-analysis of microarrays: interstudy validation of gene expression profiles reveals pathway dysregulation in prostate cancer. Cancer Res 62: 4427-4433, 2002.

88. Luo J, Duggan DJ, Chen Y, et al: Human prostate cancer and benign prostatic hyperplasia: molecular dissection by gene expression profiling. Cancer Res 61: 4683-4688, 2001.

89. Dyrskjot L, Zieger K, Real FX, et al: Gene expression signatures predict outcome in non-muscle-invasive bladder carcinoma: a multicenter validation study. Clin Cancer Res 13: 3545-3551, 2007.

90. Sanchez-Carbayo M, Socci ND, Lozano J, Saint F and Cordon-Cardo C: Defining molecular profiles of poor outcome in patients with invasive bladder cancer using oligonucleotide microarrays. J Clin Oncol 24: 778-789, 2006. 